\title{
Quality of life of patients who undergone myocardial revascularization surgery
}

\author{
Qualidade de vida de pacientes submetidos à cirurgia de revascularização do miocárdio \\ La calidad de vida de los pacientes sometidos a cirugía de revascularización del miocardio
}

\section{Hirla Vanessa Soares de Araújo', Thaisa Remigio Figueirêdo', Christefany Régia Braz Costa", Maria Mariana Barros Melo da Silveira'"', Rebeka Maria de Oliveira Belo"v, Simone Maria Muniz da Silva Bezerra'}

'Universidade de Pernambuco, School of Nurning Nossa Senhora das Graças,

Postgraduate Program in Nursing. Recife, Pernambuco, Brazil.

"Universidade de São Paulo, School of Nurning of Ribeirão Preto,

Postgraduate Program in Nursing. Ribeirão Preto, São Paulo, Brazil.

"II Universidade de Pernambuco, School of Medical Sciences,

Postgraduate Program in Medical Sciences. Recife, Pernambuco, Brazil.

${ }^{\prime v}$ Cardiac Emergency Room of Pernambuco, Multiprofessional Residency in Cardiovascular Clinical Attention.

Recife, Pernambuco, Brazil.

How to cite this article:

Araújo HVS, Figueiredo TR, Costa CRB, Silveira MMBM, Belo RMO, Bezerra SMMS. Quality of life

of patients who undergone myocardial revascularization surgery. Rev Bras Enferm [Internet]. 2017;70(2):257-64.

DOI: http://dx.doi.org/10.1590/0034-7167-2016-0201

Submission: 05-31-2016

Approval: 09-27-2016

\begin{abstract}
Objective: to evaluate the quality of life of patients who underwent revascularization surgery. Method: a descriptive, crosssectional study, with quantitative approach carried out with 75 patients. The questionnaire WHOQOL-Bref was used to evaluate the quality of life (QOL). Results: patients' QOL evaluation presented a moderate result, with need of improvement of all domains. Low income patients had the worst evaluation of QOL in the domain environment $(p=0,021)$, and the ones from Recife/metropolitan area, in the domain social relationship $(p=0,021)$. Smoker $(p=0,047)$, diabetic $(p=0,002)$ and alcohol consumption $(p=0,035)$ patients presented the worst evaluation of the physical domain. Renal patients presented the worst evaluation of QOL in the physical $(P=0,037)$, psychological $(p=0,008)$, social relationship $(p=0,006)$ domains and total score $(p=0,009)$. Conclusion: the improvement of QOL depends on the individual's process of behavioral change and the participation of health professionals is essential to formulate strategies to approach these patients, especially concerning health education.

Descriptors: Quality of Life; Thoracic Surgery, Coronary Heart Disease; Chronic Disease; Nursing.
\end{abstract}

\section{RESUMO}

Objetivo: avaliar a qualidade de vida de pacientes submetidos à cirurgia de revascularização. Método: estudo descritivo, transversal, com abordagem quantitativa realizado com 75 pacientes. Foi utilizado o questionário WHOQOL-Bref para avaliação da qualidade de vida (QV). Resultados: Pacientes apresentaram avaliação da QV regular, com necessidade de melhora em todos os domínios. Pacientes de baixa renda tiveram pior avaliação da QV no domínio meio ambiente $(p=0,021)$, e os procedentes de Recife/região metropolitana, no domínio relações sociais $(p=0,021)$. Pacientes tabagistas $(p=0,047)$, diabéticos $(p=0,002)$ e etilistas $(p=0,035)$ apresentaram pior avaliação da QV no domínio físico. Pacientes renais apresentaram pior avaliação da QV nos domínios físico $(P=0,037)$, psicológico $(p=0,008)$, relações sociais $(p=0,006)$ e no escore total $(p=0,009)$. Conclusão: a melhoria da QV depende de um processo de mudança de comportamento individual e a participação dos profissionais de saúde é essencial para elaborar estratégias de abordagem desses pacientes, principalmente no tocante à educação em saúde. Descritores: Qualidade de Vida; Cirurgia Torácica; Doença das Coronárias; Doença Crônica; Enfermagem. 


\section{RESUMEN}

Objetivo: evaluar la calidad de vida de los pacientes sometidos a cirugía de revascularización. Método: estudio descriptivo, transversal, con abordaje cuantitativo llevado a cabo con 75 pacientes. Se empleó el cuestionario WHOQOL-Bref para evaluar la calidad de vida (CV). Resultados: Los pacientes tuvieron CV regular, necesitando mejoras en todos los dominios. Los pacientes de baja renta presentaron peores índices de CV en el dominio medioambiental $(p=0,021)$, así como presentaron los provenientes de la ciudad de Recife y región en el dominio relaciones sociales $(p=0,021)$. Los pacientes fumadores $(p=0,047)$, diabéticos $(p=0,002)$ y de la clase alta $(p=0,035)$ tuvieron peores valores de CV en el dominio físico. Los pacientes con problemas renales presentaron peores índices de CV en los dominios físico $(p=0,037)$, psicológico $(p=0,008)$, relaciones sociales $(p=0,006)$ y en el puntaje total $(p=0,009)$. Conclusión: para mejorar la CV hay que cambiar la conducta individual, y es muy importante la participación de los profesionales de salud en la planificación de estrategias de abordaje a estos pacientes, en especial en la educación en salud.

Descriptores: Calidad de Vida; Cirugía Torácica; Enfermedad Coronaria; Enfermedad Crónica; Enfermería.

\section{INTRODUCTION}

Recent data from the World Health Organization (WHO) show that cardiovascular disease represent the main cause for mortality and disability in Brazil and in the world. In Brazil, Coronary Artery Disease (CAD) caused more than 100 thousand deaths in $2011^{(1)}$.

Several risk factors are associated with CAD, and are significant in all populations, such as smoking, alcohol consumption, hypertension, hypercholesterolemia, obesity, sedentary lifestyle, and low intake of fruits and vegetables ${ }^{(2)}$.

Among cardiovascular disease (CVD), CAD represents the most common cause of cardiac ischemia and may happen in different ways, from angina pectoris to acute myocardial infarction (AMI). As a form of treatment, myocardial vascularization surgery (MRV) is recommended for patients with unstable angina and for those with high levels of coronary artery occlusion. MRV aims for the improvement of quality of life (QOL) of patients, reduce angina symptoms, reestablish physical capacity, as well as increase survival - above all, of patients with higher cardiovascular risk ${ }^{(3)}$.

The impact of QOL related to MRV has been relevant purpose for study, because, beyond evaluating therapeutic results, it produces hypothesis and thoughts that suggest the increase of focus on researches about $\mathrm{QOL}^{(4)}$.

Interventions in CAD's risk factors, such as change of lifestyle, and surgical procedures may affect patients emotionally, physically and socially and their QOL as a whole. Recent studies on QOL have been carried out with patients with morbid conditions, aiming to verify the different therapeutic measures directed to the improvement of clinical conditions and patient's $\mathrm{QOL}^{(5)}$.

The concept of QOL is polysemic and WHO, in 1995 $5^{(6)}$, defined it as "individual's perception of their position in life in the context of the culture and value systems in which they live and in relation to their goals, expectations, standards and concerns". Health-related quality of life (HRQOL) may be defined as the value attributed to life's duration when modified by perception of physical and psychological limitations, social functioning and opportunities influenced by disease, treatment and other disabilities ${ }^{(7)}$.

The patient is the better source of information on their QOL, which is measured and defined according to the disease. Its improvement, from the perspective of health care, has been an expected result, both in care practices and public policies ${ }^{(8)}$.

QOL is an important matter that concerns nursing professionals. This matter requires that these professional make a trustworthy evaluation that allow them to assess the impact of a cardiac surgical procedures on patient's life, as well as to provide with subsidy based on the individual's general perception of their own health. In view of this, the objective of this research is to evaluate QOL of patients who underwent $M R V^{(9)}$.

\section{METHOD}

\section{Ethical Aspects}

According to Resolution No. 466/2012 ${ }^{(10)}$, on research involving human subjects, this study was approved by the Research Ethics Committee of the University of Pernambuco (Universidade de Pernambuco), submitted to Plataforma Brasil.

\section{Design, Place and Period of Study}

This is a cross-sectional exploratory study with quantitative approach. The study was carried out in the clinic of cardiac surgery of Cardiac Emergency Room of Pernambuco Professor Luiz Tavares (Pronto-Socorro Cardiológico de Pernambuco Professor Luiz Tavares - Procape), a referral hospital in the north and northeast region for cardiology, where interface of public policies relevant in health and education takes place. Data was collected in the days scheduled for appointments at the clinic, through private interview from June to October 2015.

Population or sample and inclusion or exclusion criteria.

The sample consisted of all individuals that met criteria for inclusion. To delimit the sample, the equation of sample size was calculated. For that, error alpha level of $5 \%$ was used, 
which corresponds to the difference between the value estimated in the research and the real value; confidence interval of $95 \%$, which is the probability of real sampling error to be lower than the sampling error accepted in the research.

The sample was corrected by a finite population, with total of 75 patients. Standard deviation used was 20.35, as reference a recent publication was considered and evaluating, through the same instrument, QOL of patients after cardiac surgery.

The individuals that participated in the research met the following inclusion criteria: to be a patient of the clinic of Procape, to be 18 years old or older and patients who have undergone MRV surgery. Patients with neurological deficits or health conditions that would make data collection impracticable were excluded.

\section{Protocol of study}

Two instruments for data collection were used. The first was a semi-structured questionnaire with objective questions to characterize social, demographic, economical and clinical data.

The second instrument was World Health Organization Quality of Life - Bref (WHOQOL-Bref), completed individually and reading with the patient. This a questionnaire with objective questions about QOL in the physical, psychological, social relationship and environment domains. This questionnaire is the short version of WHO's QOL instrument, World Health Organization Quality of Life - 100 (WHOQOL-100), translated into Portuguese, in Brazil, and into more than other 20 languages. It is a generic, short, easy management and understanding questionnaire, with 26 questions, culturally adapted to Brazilian population according to international methodology and accepted by multicentric study groups of WHO in Brazil.

The first and second questions are about QOL in general. The instrument also has other 24 facets (questions), which consist of the four domains evaluated. The answers are based on a Likert-type scale (1 to 5, the higher answer means better QOL). The scoring of facets and domains were calculated to a scale of 0 to 100 , in which the closer to 100 the value is, the better is the QOL evaluation.

\section{Results analysis and statistics}

The variables were descriptively analyzed, they were processed and analyzed with the software IBM SPSS version 20.0. Test $t$-Student was used and adapted to $p<0,05$.

\section{RESULTS}

With regard to sociodemographic data, age varied from 39 to 85 years old, average 64.96 , from this total $73.3 \%$ were 60 years old or older; $41.3 \%$ are from Recife and $37.3 \%$ are from the metropolitan area of Recife. With regard to gender, there was no significant difference, $50.7 \%$ were female. Concerning ethnic groups, $42.7 \%$ are white, $48 \%$ mixed race and $9.3 \%$ black. The majority of participants is married $(56 \%)$, have low education level $(72 \%$,$) , low income$ $(62.7 \%)$ - up to one minimum wage. Regarding work, $89.3 \%$ are not currently working.
Table 1 - Participants description according to sociodemographic variables $(\mathrm{N}=75)$, Recife, Pernambuco, Brazil, 2015

\begin{tabular}{|c|c|c|}
\hline Variables & $\mathbf{n}$ & $\%$ \\
\hline \multicolumn{3}{|l|}{ Origin } \\
\hline Recife & 31 & 41.3 \\
\hline Metropolitan area & 28 & 37.3 \\
\hline Countryside & 16 & 21.4 \\
\hline \multicolumn{3}{|l|}{ Age } \\
\hline$\geq 60$ years old & 55 & 73.3 \\
\hline Younger than 60 years old & 20 & 26.7 \\
\hline \multicolumn{3}{|l|}{ Gender } \\
\hline Male & 37 & 49.3 \\
\hline Female & 38 & 50.7 \\
\hline \multicolumn{3}{|l|}{ Ethnicity } \\
\hline White & 32 & 42.7 \\
\hline Mixed race & 36 & 48 \\
\hline Black & 7 & 9.3 \\
\hline \multicolumn{3}{|l|}{ Marital status } \\
\hline Single & 15 & 20 \\
\hline Married & 42 & 56 \\
\hline Widow & 11 & 14.7 \\
\hline Divorced & 7 & 9.3 \\
\hline \multicolumn{3}{|l|}{ Schooling } \\
\hline Until 9 years old & 54 & 72 \\
\hline$>9$ years old & 21 & 28 \\
\hline \multicolumn{3}{|l|}{ Income } \\
\hline Until 1 minimum wage & 47 & 62.7 \\
\hline 1-2 minimum wage & 16 & 21.3 \\
\hline$>2$ minimum wage & 12 & 16 \\
\hline \multicolumn{3}{|l|}{ Occupation } \\
\hline No work activity & 67 & 89.3 \\
\hline Work activity & 8 & 10.7 \\
\hline
\end{tabular}

Note: *Monthly income based on current value $(R \$ 880,00)$ of minimum wage.

With regard to clinical aspects (Table 2), 100\% have high blood pressure, $44 \%$ are diabetic, $12 \%$ present nephropathology, $98.7 \%$ claimed to be non-smokers, $94.7 \%$ claimed no alcohol consumption, $96 \%$ presented dyslipidemia and $73.3 \%$ are sedentary. Concerning medication, $72 \%$ take up to 6 medications daily. 
Table 2 - Participants description according to personal antecedents $(\mathrm{N}=75)$, Recife, Pernambuco, Brazil, 2015

\begin{tabular}{lcc}
\hline Variable & $\mathbf{n}$ & $\%$ \\
\hline Hipertension & 75 & 100 \\
Diabetic & 33 & 44 \\
Non-diabetic & 42 & 56 \\
Renal disease & 9 & 12 \\
No renal disease & 66 & 88 \\
Smoker & 1 & 1.3 \\
Non-smoker & 74 & 98.7 \\
Alcohol Consumption & 4 & 5.3 \\
No Alcohol consumption & 71 & 94.7 \\
With dyslipidemia & 72 & 96 \\
Without dyslipidemia & 3 & 42 \\
Sedentary & 55 & 26.7 \\
Non-sedentary & 20 & 73.3 \\
Medications & 54 & \\
Up to 6 medications & 21 & \\
(6 medications & & \\
\hline & & \\
\hline
\end{tabular}

Table 3 shows results of average and standard deviation of physical, psychological, social relations and environment domains and patient's QOL self-evaluation.

Regarding facets scoring on a 0 to 100 scale of WHOQOLBref, the results for physical domain are: pain and discomfort (34.67); energy and fatigue (50.00); sleep and rest (58.33); mobility (54.67); activities of daily living (51.00); dependence on medical substances and medical aid (65.33); and work capacity (47.33). Concerning psychological domain, the facets are: positive feelings (51.00); thinking, learning, memory and concentration (60.00); self-esteem (68.67), bodily image and appearance (75.67); negative feelings (34.67); spirituality, religion and personal beliefs (64.67)

With regard to social relationships domain, the facets are: personal relationships (72.00), social support (67.67), and sexual activity (51.33). Regarding environment domain, the facets are: freedom, physical safety and security (55.00); home environment (68.33), financial resources (37.67); health and social care: accessibility and quality (57.00); opportunities for acquiring new information and skills (57.67); participation in and opportunities for recreation/ leisure activities (42.67); physical environment: (pollution/noise/traffic/climate) (65.00); and transport (50.00).

Some facets do not show a positive association (pain and discomfort, negative feelings, dependence on medical substances and medical aid), which means that for these facets, high scorings do not indicate better QOL. Therefore, these scorings need to be inverted so that higher values indicate better evaluation of QOL.

With regard to scoring for each domain, psychological presented better result (64.22), followed by social relationship (63.67), environment (54.17) and physical (51.62) domains. The total scoring was 57.44 . These results show that all domains present results for which QOL needs improvement.

Table 4 shows results of QOL evaluation according to sociodemographic and clinical variables. Data statistically significant present $p<0,005$.

Concerning sociodemographic variables, patients from Recife/metropolitan area present worst evaluation of social relationships domain $(p=0021)$ and low income patients had the worst evaluation of environment domain $(p=0,021)$. Regarding clinical variables, diabetics $(p=0.002)$, smokers $(p=0.047)$ and alcohol consumption $(p=0.035)$ had the worst physical domain evaluation.

Renal patients had worst evaluation of QOL in physical $(p=0.037)$, psychological $(p=0.008)$, and social relationship $(p=0.006)$ domain, and total scoring evaluation $(p=0.009)$.

Table 3 - Average and standard deviation of quality of life evaluation in physical, psychological, social relations and environment domains ( $N=75)$, Recife, Pernambuco, Brazil, 2015

\begin{tabular}{|c|c|c|c|c|c|c|}
\hline Domain & Average & $\begin{array}{l}\text { Standard } \\
\text { Deviation }\end{array}$ & $\begin{array}{l}\text { Coefficient } \\
\text { of variation }\end{array}$ & $\begin{array}{l}\text { Minimum } \\
\text { value }\end{array}$ & $\begin{array}{l}\text { Maximum } \\
\text { value }\end{array}$ & Amplitude \\
\hline Physical & 12.26 & 3.34 & 27.20 & 5.71 & 19.43 & 13.71 \\
\hline Psychological & 14.28 & 3.13 & 21.95 & 6.67 & 20.00 & 13.33 \\
\hline Social Relationship & 14.19 & 2.92 & 20.59 & 5.33 & 20.00 & 14.67 \\
\hline Environment & 12.67 & 2.59 & 20.43 & 7.00 & 20.00 & 13.00 \\
\hline Quality of life self-evaluation & 13.79 & 3.30 & 23.92 & 6.00 & 20.00 & 14.00 \\
\hline Total & 13.19 & 2.55 & 19.33 & 7.23 & 19.85 & 12.62 \\
\hline
\end{tabular}




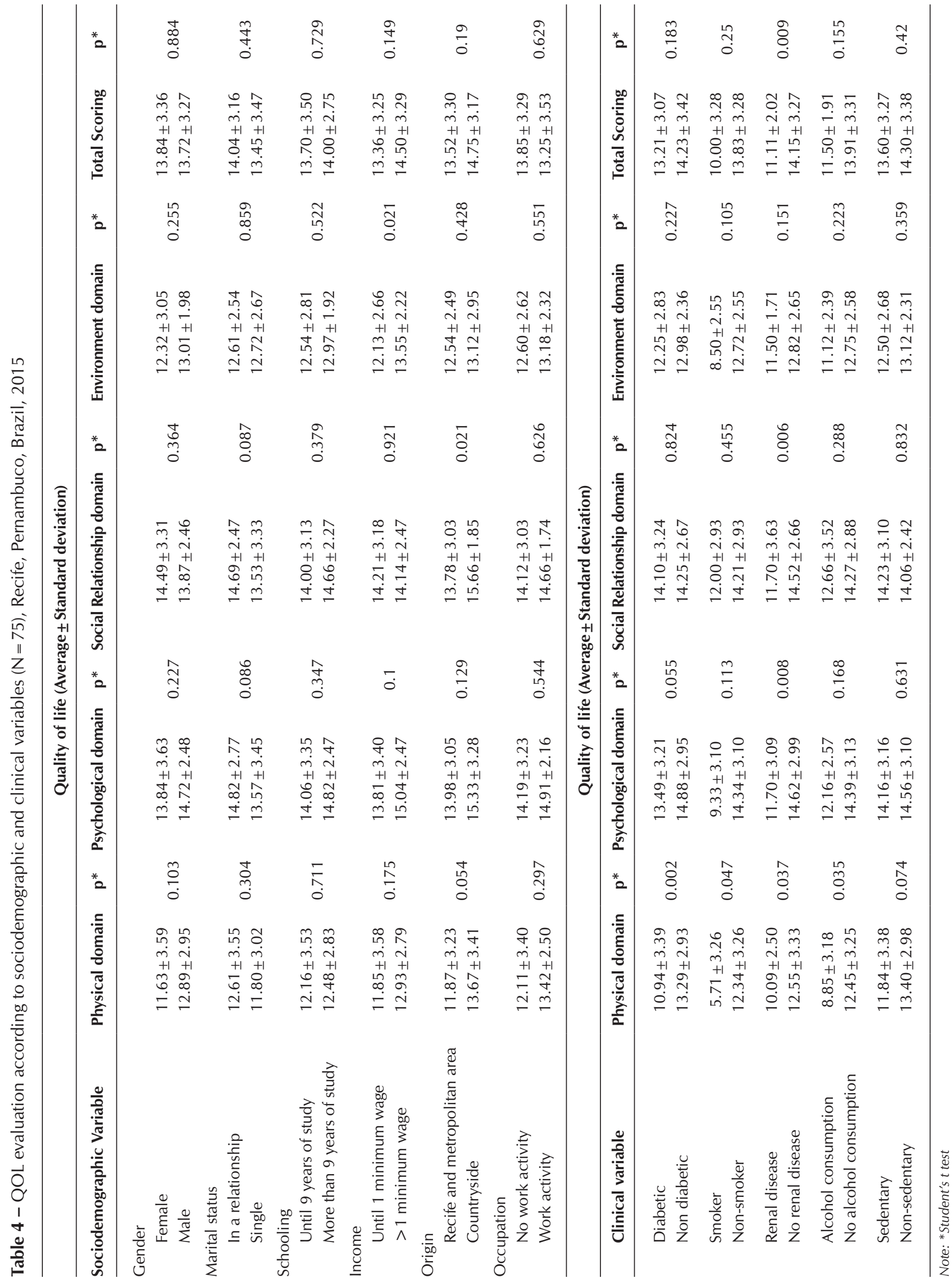




\section{DISCUSSION}

Results show a population predominantly from Recife/metropolitan area, elderly, low education level and low income. There was no significant difference between the number of male and female participants, and a large part of them do not currently work, most of them are retired and pensioners.

A study that evaluated QOL of 38 patients in post-operative period of cardiac surgery shows data that corroborate with this research, in which most of patients are married, have low level of education and low income, however, only half of participants receive financial aid from the government ${ }^{(11)}$.

Results of the research and of other study ${ }^{(11)}$, show average age similar to others that evaluated QOL of cardiac patients ${ }^{(13)}$. This data may be explained by the fact that CVD affects mainly older individuals.

With regard to patients having low level of education, it is estimated that the understanding of health orientation and medication treatment prescribed during appointments may be significantly compromised, resulting in risk factor for cardiovascular complications after revascularization surgery.

It is important to emphasize that, educational level does not only express the difference in information accessibility and perspective to benefit from new knowledge, but has a great importance as health determinant ${ }^{(14)}$.

Concerning ethnicity, less favorable groups, such as black population, present consequences of cardiovascular complications more often and higher mortality caused by hypertension, as well as being the primary group responsible for economic impact of non-communicable disease, consequently in its complications ${ }^{(15)}$. However, considering the high race miscegenation in Brazil and regional characteristics of the population, it is difficult to measure the exact influence of this variable ${ }^{(16)}$.

Regarding income, there was statistically significance between this variable and evaluation of QOL by the instrument used for research, in which patients with lower income presented worse evaluation of QOL. A study on the repercussions regarding hypertension treatment ${ }^{(17)}$ revealed that with regard to socioeconomic development, lower levels present higher prevalence of risk factor of CVD.

Concerning work, the majority of participants do not currently work, which may be justified by older age, that leads to retirement, women widowhood, to which the only source of income are pensions, and unemployment, or for the lack of job opportunities or physical limitations caused by chronic disease.

Results regarding clinical variables show that patients present comorbidities, all of them have hypertension, as well as other important cardiovascular risk factors, as diabetes, dyslipidemia and sedentary lifestyle.

Another study shows similar results for following medical instructions of 92 patients with CAD, all patients had hypertension - and $95.7 \%$ had dyslipidemia and $75 \%$ were sedentary The risk factor sedentary lifestyle was the only one with similar values in studies that evaluated QOL of patients who have chronic disease and underwent MRV, representing $71.9 \%{ }^{(16)}$.

Risk factors such as hypertension may influence QOL of patients that have MRV, in the need of change of lifestyle and also in the disease diagnosis, which causes them to be aware of silent symptoms and think of the disease as a mortality factor. Moreover, diabetes associated with hypertension increases the cardiovascular risk (twice as much than non-diabetic hypertension patients) and may accelerate not only macrovascular lesion, such as cerebrovascular accident, CAD or peripheral artery disease ${ }^{(19)}$.

It is important to mention that, regarding clinical variables, after a cardiac event it is necessary to establish measures directed to following medical orientations, but also directed to changing lifestyle, since the best therapy is prevention, reducing risk factors ${ }^{(11)}$.

With regard to the number of medications, the amount represents high values, however, it is possible to conclude that, regardless of the amount of medication, the control of therapeutic regimen is referred by patients.

Following medical orientation is the primary factor for reduction of high cardiovascular complications rates among patients. It is necessary a systematic evaluation of care including strategies that emphasize the importance of following medical orientations in the face of a high number of medications ${ }^{(20)}$.

The evaluation of QOL by the instrument WHOQOL-Bref presents results regarding physical, psychological, social relationship and environment domains. The scoring of the evaluation of QOL shows values relatively low and the domain with worst evaluation was physical, which may be cause by the clinical condition of patients of the research. QOL evaluation in general was moderate.

In one study, the average of all domains show higher values than this research, 62.9 for physical, 76.1 for psychological, 74.3 for social relationship and 69.2 for environment domain. For the total evaluation of QOL the result was 75, showing a better evaluation of QOL.

With regard to physical domain, results show the need of improvement. There was statistically significance for diabetic, smokers and alcohol consumption patients, who presented the worst evaluation of QOL for this domain. In a study on QOL and risk factors for non-communicable diseases, the analysis of smokers, alcohol consumption and obesity were associated with a worse evaluation of QOL for physical aspect.

Considering that diabetic patients also have hypertension, values of arterial pressures or its control benefit in the reduction of cardiovascular risk and, consequently, the increase of probability of having a fatal or non-fatal event.

Still regarding these factors, smoking is the most important changeable risk factor among young and elderly individuals and represents the most avoidable premature death. Nicotine increases blood pressure and leads to a higher presence of cholesterol in blood vessels ${ }^{(21)}$.

Alcohol may protect against stroke or coronary disease in individuals that are 45 years old or older, however, in terms of general mortality, adverse effects of drinking prevail over any protection against CAD, even in a high risk population. An important matter when dealing with hypertension patients is the cardiovascular rebound mechanism after repeated alcohol consumption, as well as being an important central nervous system depressant.

Several studies ${ }^{(22)}$ show effects of lifestyle intervention programs in high risk population, and some presented significant decrease in diabetes incidence, others showed beneficial 
effects on changing lifestyle over blood pressure control. Interventions in lifestyle seem to be more effective in medicamental treatments. Therefore, lifestyle change should be considered the pillar of interventions.

Social relationship domain presented the second higher score. Social support may relieve stress in crisis situations, inhibit the development of disease and represent an important role in recovery of existing illness, Being considered a protection factor and, therefore, is an important focus of intervention in this specific population ${ }^{(19)}$.

Patients from Recife and metropolitan area present the worse evaluation of QOL for this domain. The result may be justified by the fact that patients live in large urban area (which public transportation does not facilitate mobility), are from a low socioeconomic level, have low level of education, or also because the majority is sedentary. In a study of Aguiar and Farias ${ }^{(23)}$ on QOL of patients who underwent heart transplant, participants had a better perception of social relationship domain with significant data with regard to exercising, which brings patients closer to friends and family, improving their social relationship.

Regarding environment domain, low income patients, that earn up to one minimum wage, present the worse evaluation of QOL for this domain. The facet financial resources contributed to obtaining this evaluation, since $84 \%$ presented income lower than two minimum wages. The fact that most of them are elderly and retired/pensioner also contributed to this evaluation. Income frequently decreased is an important socioeconomic factor of daily living and QOL, especially for elderly. Low income should also be considered when evaluating the clinical status of patients and the use of a larger amount of medication ${ }^{(24)}$.

Regarding psychological domain, patients showed a better perception of QOL. All facets contributed to this result, except the facet negative feeling. Negative feeling cause physiological change with negative impact on CAD prognosis and may influence directly in following medical orientation that requires behavioral change ${ }^{(25)}$.
Renal patients had a worse evaluation of QOL in physical, psychological and social relationship domains, which also contributes to a worse total evaluation of QOL. Data of a study on QOL of patients who have renal failure corroborate with the research, indicating that renal patients have lower impact on QOL regarding environment domain. Concerning other domains, a longer period of having the disease resulted in a higher commitment to QOL of patients ${ }^{(26)}$.

\section{Limitations of the study and contributions to nursing, health and public policies}

This study shows limitations regarding the sample size and short period for data collection. Therefore, results should not be generalized, but should be analyzed with the purpose of establishing actions that aim to improve quality of life of these patients. In view of this, the expectation is that this study motivates other researches and discussions increasing knowledge about this subject.

\section{CONCLUSION}

Patients who undergone MRV surgery had lower scoring in physical and environment domains and association between risk factors and comorbities with worse evaluation of QOL.

The matters regarding QOL of patients in post-operative of cardiac surgery allow consideration of the real necessity of these patients concerning their health condition, personal satisfaction, which may directly help health professional involved in rehabilitation planning, providing subsidy to establish assistance care directed to their real needs, with strategies of health education, as a way to promote health and prevent disabilities.

To comprehend this dimension with another view besides the obvious of clinical conditions seems to provide better perspective of different ways of thinking and acting in health, considering specificity of human beings.

\section{REFERENCES}

1. Mattos LAP, Berwanger O, Santos ES, Reis HJL, Romano ER, Petriz JLF, et al. Clinical outcomes at 30 days in the Brazilian registry of acute coronary syndromes (ACCEPT). Arq Bras Cardiol[Internet]. 2013[cited 2015 Dec 20];100(1):6-13. Available from: http://www.scielo.br/ pdf/abc/v100n1/en_v100n1a03.pdf

2. Feijó MKEF, Lutkmeier R, Ávila CW, Rabelo ER. Fatores de risco para doença arterial coronariana em pacientes admitidos em unidade de hemodinâmica. Rev Gaúcha Enferm[Internet]. 2009[cited 2015 Dec 20];30(4):641-7. Available from: http:// www.scielo.br/pdf/rgenf/v30n4/a09v30n4.pdf

3. Gois CFL, Dantas RAS, Torrati FG. Qualidade de vida relacionada à saúde antes e seis meses após a revascularização do miocárdio. Rev Gaúcha Enferm[Internet]. 2009[cited 2015 Dec 20];30(4):700-7. Available from: http://www.scielo.br/pdf/rgenf/v30n4/ a17v30n4.pdf

4. Boni ALMD, Martinez JE, Saccomann ICRS. Quality of life of patients undergoing coronary artery bypass grafting. Acta Paul Enferm[Internet]. 2013[cited 2015 Dec 28];26(6):575-80. Available from: http://www.scielo.br/pdf/ape/v26n6/en_11.pdf

5. Takiuti ME, Hueb W, Hiscock SB, Nogueira CRSR, Girardi P, Fernandes F, et al. Quality of life after surgical myocardial revascularization, angioplasty or medical treatment. Arq Bras Cardiol[Internet]. 2007[cited 2016 Jan 02];88(5):475-81. Available from: http://www.scielo.br/pdf/abc/v88n5/en_a07v88n5.pdf

6. The WHOQOL Group. The World Health Organization quality of life instruments (WHOQOL): development and general psychometric properties. Soc Sci Med[Internet]. 1998[cited 2016 Jan 02];46(12):1569-85. Available from: http://www.psychology.hku.hk/ ftbcstudies/refbase/docs/thewhoqolgroup/1998/71_TheWHOQOLGroup1998.pdf 
7. Arbex FS, Almeida EA. Qualidade de vida e hipertensão arterial no envelhecimento. Rev Bras Clin Med[Internet]. 2009 [cited 2016 Jan 03];7:339-42. Available from: http://files.bvs.br/upload/S/1679-1010/2009/v7n5/a012.pdf

8. Freire MEM, Sawada NO, França ISX, Costa SFG, Oliveira CDB. Health-related quality of life among patients with advanced cancer: an integrative review. Rev Esc Enferm USP[Internet]. 2014[cited 2016 Apr 28];48(2):357-67. Available from: http://www.scielo.br/pdf/ reeusp/v48n2/0080-6234-reeusp-48-02-357.pdf

9. Bezerra SMMS, Veiga EV. Quality of life among people with hypertension served in units of family health strategies. J Nurs UFPE on line[Internet]. 2013[cited 2016 Jan 05];7(spe):7055-63. Available from: http://www.revista.ufpe.br/revistaenfermagem/index. php/revista/article/viewArticle/5203

10. Brasil. Conselho Nacional de Saúde. Resolução n 466, de 12 de dezembro de 2012. Brasília, DF, 2012 [cited 2016 Dec 12 ]. Available from: http://bit.ly/1mTMIS3

11. Custódio FM, Gasparino RC. Quality of life of patients in the postoperative cardiac surgery phase. REME Rev Min Enferm[Internet]. 2013[cited 2016 Jan 17];17(1):125-9. Available from: http://www.reme.org.br/artigo/detalhes/584

12. Flek MPA, Leal OF, Louzada S, Xavier M, Chachamovich E, Vieira G, et al. Desenvolvimento da versão em português do instrumento de avaliação de qualidade de vida da OMS (WHOQOL-100). Rev Bras Psiquiatr[Internet]. 1999[cited 2016 Jan 05];21(1):1928. Available from: http://www.scielo.br/pdf/rbp/v21n1/v21n1a06.pdf

13. Dantas RAS, Rossi LA, Costa MCS, Vila VSC. Qualidade de vida após revascularização do miocárdio: avaliação segundo duas perspectivas metodológicas. Acta Paul Enferm[Internet]. 2010[cited 2016 Jan 17];23(2):163-8. Available from: http://www.scielo.br/pdf/ ape/v23n2/02.pdf

14. Badziak RPF, Moura VEV. Determinantes sociais da saúde: um conceito para efetivação do direito à saúde. Rev Saúde Públ Santa Cat[Internet]. 2010[cited 2016 Jan 17];3(1):69-79. Available from: http://esp.saude.sc.gov.br/sistemas/revista/index.php/inicio/ article/view/51/114

15. Rocha-Brischiliari SC, Agnolo CMD, Gravena AAF, Lopes TCR, Carvalho MDB, Peloso SM. Doenças crônicas não transmissíveis e associação com fatores de risco. Rev Bras Cardiol[Internet]. 2014[cited 2016 Mar 17];27(1):35-42. Available from: http://www. rbconline.org.br/wp-content/uploads/Art 52 RBC 271 Catia Agnollo Artigo Original1.pdf

16. Oliveira TRP, Pedrosa LAK, Gonçalves RMDA. Estudo da hipertensão arterial sistêmica: repercussões quanto a adesão ao tratamento. Rev Triângulo[Internet]. 2008[cited 2016 Mar 17];1(9):97-110. Available from: http://seer.uftm.edu.br/revistaeletronica/index.php/ revistatriangulo/article/view/50/73

17. Lunelli RP, Portal VL, Esmério FG, Moraes MA, Souza EN. Patients' with coronary arterial disease' adherence to pharmacological and non-pharmacological therapy. Acta Paul Enferm[Internet]. 2009[cited 2016 Jan 28];22(4):367-73. Available from: ttp://www.scielo.br/pdf/ ape/v22n4/en_a03v22n4.pdf

18. Christmann M, Costa CC, Moussale LD. Avaliação da qualidade de vida de pacientes cardiopatas internados em um hospital público. Rev AMRIGS[Internet]. 2011 [cited 2016 Jan 28];55(3):239-43. Available from: http://www.amrigs.org.br/revista/55-03/0000045956-Revista AMRIGS_3_artigo_original_avaliada_qualidade_de_vida.pdf

19. Souza AO, Yamaguchi MU. Adesão e não adesão dos idosos ao tratamento anti-hipertensivo. Saúde Pesq[Internet]. 2015[cited 2016 Jan 29];8(spe):113-22. Available from: http://periodicos.unicesumar.edu.br/index.php/saudpesq/article/view/3769/2518

20. Campos MO, Rodrigues JF Neto. Qualidade de vida e fatores de risco para as doenças crônicas não transmissíveis em Montes Claros, Minas Gerais. RBSP[Internet]. 2011[cited 2016 Jan 29];35(4):1013-5. Available from: http://inseer.ibict.br/rbsp/index.php/rbsp/article/ viewFile/268/pdf_81

21. Lopes NP, Salzbron CA, Barroso MC, Ribeiro SJP, Webber, JS, Borges BE, et al. Perfil de fatores determinantes da HAS de uma população específica em uma região delimitada de Curitiba-PR. Rev Curso Enferm[Internet]. 2012[cited 2016 Feb 01];1(1):1-11. Available from: http://www.santacruz.br/ojs/index.php/Revenf/article/view/1006/930

22. Chaves G, Britez N, Munzinger J, Uhlmann L, Gonzalez G, Oviedo G, et al. Education to a healthy lifestyle improves symptoms and cardiovascular risk factors: AsuRiesgo Study. Arq Bras Cardiol[Internet]. 2015[cited 2016 Feb 01];104(5):347-55. Available from: http://www.scielo.br/pdf/abc/v104n5/0066-782X-abc-20150021.pdf

23. Aguiar, MIFA, Farias DR, Pinheiro ML, Chaves ES, Rolim ILTP, Almeida PC. Quality of life of patients that had a heart transplant: application of WHOQOL-Bref scale. Arq Bras Cardiol[Internet]. 2011[cited 2016 Feb 02];96(1):60-7. Available from: http://www.scielo.br/pdf/ abc/2010nahead/aop12910

24. Alberte JSP, Ruscalleda RMI, Guariento ME. Qualidade de vida e variáveis associadas ao envelhecimento patológico. Rev Soc Bras Clin Med [Internet]. 2015 [cited 2016 Feb 02];13(1):32-9. Available from: http://files.bvs.br/upload/S/1679-1010/2015/v13n1/a4766.pdf

25. Bonomo MAS, Araújo TCCF. Psicologia aplicada à cardiologia: um estudo sobre emoções relatadas em exame de Holter. Psic: Teor e Pesq[Internet]. 2009[cited 2016 Feb 02];25(1):065-074. Available from: http://www.scielo.br/pdf/ptp/v25n1/a08v25n1.pdf

26. Nepomuceno FCL, Melo Jr IM, Silva EA, Lucena KDT. Religiosidade e qualidade de vida de pacientes com insuficiência renal crônica em hemodiálise. Saúde Debate[Internet]. 2014[cited 2016 Feb 02];38(100):119-28. Available from: http://www.scielo.br/pdf/sdeb/ v38n100/0103-1104-sdeb-38-100-0119.pdf 